\title{
SERUM COPPER AND ITS RELATIONSHIP TO SERUM IRON IN PATIENTS WITH NEOPLASTIC DISEASE
}

\author{
BY \\ ROBERT PIRRIE \\ From the Muirhead Department of Medicine, the University and Royal \\ Infirmary, Glasgow
}

(RECEIVED FOR PUBLICATION JULY 10, 1951)

The importance of serum copper in the transport of copper throughout the body was established by Sachs, Levine, Schmit, and Hughes (1941) when they observed that the oral administration of varying amounts of copper sulphate was followed by a definite rise in the copper content of the serum. Later Yoshikawa, Hahn, and Bale (1942) obtained a similar result by feeding radio-active copper salts to normal and anaemic dogs. After its ingestion the tagged metal rapidly appeared in the serum, reaching its peak concentration within two to five hours. These observations indicate that the role of serum copper in copper metabolism is analogous to that of serum iron in iron metabolism, and, by permitting valid conclusions to be drawn from estimations of serum copper levels, have facilitated the study of copper metabolism in man.

The purpose of this paper is to present the values of serum copper obtained in normal subjects and in patients with neoplastic disease unaccompanied by haemorrhage, and to compare the iron and copper concentrations ị the serum of these patients.

\section{Methods}

Serum copper was determined by a minor modification of the technique described by Cartwright, Jones, and Wintrobe (1945). This method consists of the triple extraction of the trichloracetic acid precipitate of serum and the development of the coloured copper-dithiocarbamate complex, the resultant colour being measured directly in the aqueous extract. Difficulty was encountered in obtaining optically clear aqueous extracts for photometry, however, and extraction of the coloured complex with amyl alcohol, as originally suggested by McFarlane (1932), was therefore employed. The procedure finally adopted was as follows. The aqueous phase, obtained by following the procedure of Cartwright $e t$ al., was made up to a volume of $20 \mathrm{ml}$. with distilled water in a graduated test-tube, $10 \mathrm{ml}$. of amyl alcohol added, and the test tube shaken vigorously for two minutes. The amyl alcohol phase was then separated by centrifugalization and transferred by a Pasteur pipette to a thoroughly dried $1 \mathrm{~cm}$. optical cell. Colour was measured in a Spekker absorptiometer using the Ilford spectrum filter, No. 601. Clear extracts of the coloured copper complex were consistently obtained when this procedure was followed.

Serum iron was estimated by the method of Fitzpatrick and Howells (1949), by whom it has already been described in detail. The Haldane method was used for haemoglobin determination. 


\section{Results}

Copper was estimated in triplicate in five different sera (Table I) and the results showed good agreement, the maximum difference being $4.5 \%$.

TABLE I

Triplicate Estimations of Serum Copper

\begin{tabular}{c|c|c|c}
\hline Serum & \multicolumn{3}{|c}{ Copper Content $(\mu \mathrm{g} . \%)$} \\
\hline 1 & 89 & 93 & 93 \\
2 & 151 & 150 & 153 \\
3 & 326 & 326 & 324 \\
4 & 115 & 112 & 112 \\
5 & 110 & 115 & 115 \\
\hline
\end{tabular}

In 20 healthy adult males, the mean and its standard error of serum copper values were $105 \pm 5.74 \mu \mathrm{g}$. \% with a range of 74 to $151 \mu \mathrm{g}$. \%. The corresponding values in 20 healthy adult females were $120 \pm 6.72 \mu \mathrm{g}$. \% and 84 to $168 \mu \mathrm{g}$. \%. This difference between the sexes was not significant. These results compare favourably with those already reported (Table II); only in the series of Nielsen (1944a) and Munch-Petersen (1948) is the observed sex difference in serum copper significant.

TABLE II

Summary of Published Data on Serum Copper in Normal Subjects

\begin{tabular}{|c|c|c|c|c|c|c|c|c|c|}
\hline & & & & \multicolumn{6}{|c|}{ Serum Copper $(\mu \mathrm{g} . \%)$} \\
\hline \multirow{2}{*}{\multicolumn{4}{|c|}{. Investigator }} & \multicolumn{3}{|c|}{ Males } & \multicolumn{3}{|c|}{ Females } \\
\hline & & & & No. & Mean & Range & No. & Mean & Range \\
\hline $\begin{array}{l}\text { Nielsen (1944a) } \\
\text { Cartwright } \text { et al. (1945) } \\
\text { Munch-Petersen (1948) } \\
\text { Cartwright et al. (1948) } \\
\text { Brendstrup (1948) } \\
\text { Present investigation }\end{array}$ & $\begin{array}{l}\ldots \\
\cdots \\
\cdots \\
\cdots \\
\cdots\end{array}$ & $\begin{array}{l}\cdots \\
\cdots \\
\cdots \\
\cdots \\
\cdots\end{array}$ & $\begin{array}{l}\cdots \\
\cdots \\
\cdots \\
\cdots \\
\cdots\end{array}$ & $\begin{array}{l}30 \\
25 \\
50 \\
52 \\
40 \\
20\end{array}$ & $\begin{array}{l}110 \\
116 \\
108 \\
114 \\
113 \\
105\end{array}$ & $\begin{array}{l}75-165 \\
92-134 \\
81-164 \\
86-141 \\
84-162 \\
74-151\end{array}$ & $\begin{array}{r}100 \\
25 \\
50 \\
53 \\
40 \\
20\end{array}$ & $\begin{array}{l}123 \\
131 \\
118 \\
123 \\
120 \\
120\end{array}$ & $\begin{array}{r}75-165 \\
103-159 \\
73-152 \\
87-161 \\
89-152 \\
84-168\end{array}$ \\
\hline
\end{tabular}

Serum copper and serum iron were determined in 19 patients with malignant disease unaccompanied by haemorrhage, and the results are set out in Table III. The mean value for serum copper in these patients was $223 \pm 14.18 \mu \mathrm{g}$. $\%$; the difference between serum copper levels in these patients and those of normal subjects was highly significant. The values for serum iron had a mean of $67 \pm 5.96 \mu \mathrm{g}$. \% and were significantly lower than those obtained in normal subjects by the potassium ferricyanide method (Pirrie, 1952). In Fig. 1 serum copper results are plotted against serum iron results, the latter being grouped in $20 \mu \mathrm{g}$. units. The relationship between the two is approximately linear, and the individual results for serum copper were found to show a statistically significant inverse correlation to those for serum iron. No significant correlation between serum copper and haemoglobin was established in this series. Thus, of the five patients whose haemoglobin and red cell counts were within normal limits, three had elevated serum copper and lowered serum iron. 
TABLE III

Serum Copper and Serum Iron in Patients with Neoplastic Disease Unaccompanied BY HAEMORRHAGE

\begin{tabular}{|c|c|c|c|c|c|c|c|c|c|c|}
\hline \multicolumn{5}{|c|}{ Diagnosis } & \multirow{2}{*}{$\begin{array}{c}\begin{array}{c}\text { Age } \\
\text { (yrs.) }\end{array} \\
54\end{array}$} & \multirow{2}{*}{$\begin{array}{c}\text { Sex } \\
\text { M. }\end{array}$} & \multirow{2}{*}{$\begin{array}{c}\begin{array}{l}\text { Hb. } \\
(\%)\end{array} \\
114\end{array}$} & \multirow{2}{*}{$\begin{array}{c}\begin{array}{c}\text { R.B.C. } \\
\left(\times 10^{6}\right.\end{array} \\
\text { c.mm. })\end{array}$} & \multirow{2}{*}{$\begin{array}{c}\begin{array}{c}\text { Serum } \\
\text { Copper } \\
(\mu \mathrm{g} . \%)\end{array} \\
184\end{array}$} & \multirow{2}{*}{$\begin{array}{c}\left.\begin{array}{c}\text { Serum } \\
\text { Iron } \\
(\mu \mathrm{g} . \%)\end{array}\right) \\
73\end{array}$} \\
\hline Carcinor & lung & . & . & . & & & & & & \\
\hline , & ", & & & & $\begin{array}{l}61 \\
62\end{array}$ & M. & $\begin{array}{l}64 \\
74\end{array}$ & $\overline{4 \cdot 25}$ & $\begin{array}{l}325 \\
211\end{array}$ & $\begin{array}{l}40 \\
96\end{array}$ \\
\hline ", & ,", & & & & $\begin{array}{l}02 \\
38\end{array}$ & M: & 74 & 3.92 & 326 & 65 \\
\hline ," & ,", & & & & 39 & M. & 89 & - & 178 & 57 \\
\hline ,", & ," & & & & 43 & M. & 70 & 3.85 & 211 & 67 \\
\hline , & , & & & & 67 & M. & 89 & 5.01 & 311 & 43 \\
\hline ", & & & & & 40 & M. & 58 & 3.65 & 228 & 35 \\
\hline 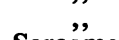 & ,", & & & & 63 & M. & 122 & 6.51 & 151 & 110 \\
\hline Sarcöma & mur & $\cdots$ & . & .. & 35 & M. & 70 & 3.94 & 262 & 56 \\
\hline Carcinor & prostate & .. & . & .. & 69 & M. & 102 & $5 \cdot 49$ & 174 & 95 \\
\hline ", & , & & & & $\begin{array}{r}71 \\
58\end{array}$ & $\mathbf{M}$. & 106 & $6 \cdot 12$ & 193 & $\begin{array}{r}81 \\
105\end{array}$ \\
\hline Carcinor & tongue & & & .. & 67 & M. & 88 & 5.02 & $\begin{array}{l}138 \\
178\end{array}$ & 43 \\
\hline Carcinor & penis & & $\therefore$ & .. & 71 & M. & 105 & 5.62 & 124 & 105 \\
\hline Carcinor & oesophag & & $\ldots$ & $\ldots$ & 59 & M. & 84 & 4.91 & 263 & 30 \\
\hline Carcinor & breast & & .. & .. & 67. & F. & 104 & $5 \cdot 84$ & 213 & 74 \\
\hline ", & ," & & & & $\begin{array}{l}58 \\
38\end{array}$ & F. & $\begin{array}{r}82 \\
106\end{array}$ & $\begin{array}{l}4 \cdot 45 \\
5 \cdot 37\end{array}$ & $\begin{array}{l}293 \\
245\end{array}$ & $\begin{array}{l}40 \\
50\end{array}$ \\
\hline "” & " & & & & & & & & & \\
\hline
\end{tabular}

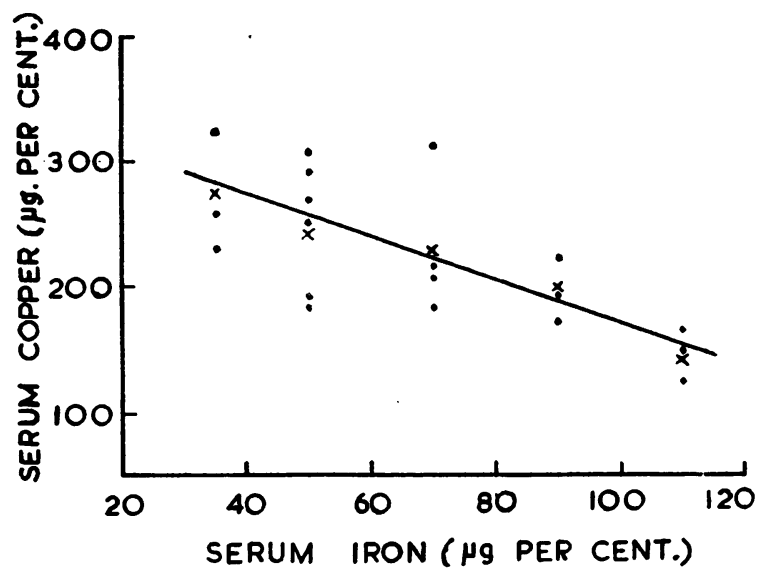

Fig. 1.-The relationship between serum copper and serum iron in patients with malignant disease unaccompanied by haemorrhage. Individual results of serum copper (O). Mean serum copper of serum iron groups $(\mathbf{x})$.

\section{Discussion}

The effect of various diseases upon serum copper has already been studied. Hypocupraemia is rarely found and is not apparently peculiar to any particular clinical entity. Hypercupraemia occurs in thyrotoxicosis (Nielsen, 1944b), in infectious mononucleosis (Munch-Petersen, 1948), in both acute and chronic infections (Cartwright, Lauritsen, Jones, Merrill, and Wintrobe, 1946), and in pregnancy, in which it appears after the third month and persists until four to seven weeks after parturition (Nielsen, 1944c). In addition, Cartwright, Huguley, Ashenbrucker, Fay, and Wintrobe (1948) have described its occurrence in iron deficiency anaemia, in nephritis with anaemia, and in leukaemia and lymph node disorders. 
The significance of hypercupraemia and of the inverse correlation between the degrees of hypercupraemia and hypoferraemia, which were observed in these patients with neoplastic disease, is difficult to assess at present. The assumption that the two metals compete for the same metal-combining protein in the plasma is unjustified in the light of the work of Holmberg and Laurell (1947). The ironcombining protein is a $\beta_{1}$-globulin, and, although it can combine with copper in vitro, (Surgenor, Koechlin, and Strong, 1949) there is no evidence to show that it does so in vivo. On the contrary, Holmberg and Laurell (1947) have shown that the main part of native serum copper is found in the $\alpha$-globulin fraction of the serum. In this connexion, it is interesting to note that there is a conspicuous increase in $\alpha_{2}$-globulins in the serum of patients with neoplastic disease (Shedlovsky and Scudder, 1942 ; Seibert, Seibert, Atno, and Campbell, 1947).

The occurrence of anaemia in these patients even in the absence of blood loss demonstrates that haemoglobin synthesis is depressed or deranged in the presence of neoplastic disease. A reduced demand for copper, an essential catalyst in haemoglobin synthesis, may be the explanation of the observed hypercupraemia.

\section{Summary}

Mean values of $105 \pm 5.74 \mu \mathrm{g} . \%$ and $120 \pm 6.72 \mu \mathrm{g} . \%$ were established for serum copper in 20 healthy adult males and 20 healthy adult females respectively. This sex difference was not significant.

Serum copper levels in 19 patients with neoplastic disease unaccompanied by haemorrhage were significantly higher than normal, and serum iron was significantly lower.

A significant inverse correlation between serum copper and serum iron was observed in these patients.

These findings are briefly discussed.

While this investigation was being carried out, the author was Faulds Research Fellow in Medicine of Glasgow University and part of the expenses incurred was provided by the Rankin Fund.

I wish to thank Professor L. J. Davis for his advice during the preparation of this paper.

\section{REFERENCES}

Brendstrup, P. (1948). Ugeskr. Laeg., 110, 945.

Cartwright, G. E., Huguley, C. M., Ashenbrucker, H., Fay, J., and Wintrobe, M. M. (1948). Blood, 3, 501 .

_ Jones, P. J., and Wintrobe, M. M. (1945). J. biol. Chem., 160, 593.

Lauritsen, M. A., Jones, P. J., Merrill, I. M., and Wintrobe, M. M. (1946). J. clin. Invest., 25,65 .

Fitzpatrick, J., and Howells, K. W. (1949). Journal of Clinical Pathology, 2, 290.

Holmberg, C. G., and Laurell, C. B. (1947). Acta chem. scand., 1, 944.

McFarlane, W. D. (1932). Biochem. J., 26, 1022.

Munch-Petersen, S. (1948). Acta med. scand., 131, 588.

Nielsen, A. L. (1944a). Ibid., 118, 87. (1944b). Ibid., 118, 431.

(1944c). Ibid., 118, 92.

Pirrie, R. (1952). Journal of Clinical Pathology, 5, 10.

Sachs, A., Levine, V. E., Schmit, A., and Hughes, R. (1941). Proc. Soc. exp. Biol., N.Y., 46, 192.

Seibert, F. B., Seibert, M. V., Atno, A. J., and Campbell, H. W. (1947). J. clin. Invest., $26,90$.

Shedlovsky, T., and Scudder, J. (1942). J. exp. Med., 75, 119.

Surgenor, D. M., Koechlin, B. A., and Strong, L. E. (1949). J. clin. Invest., $28,73$.

Yoshikawa, H., Hahn, P. F., and Bale, W. F. (1942). J. exp. Med., 75, 489. 